\title{
Strategies on Improving English Course Information Teaching Level in Higher Vocational College
}

\author{
Ying Zhang \\ Tianjin Vocational Institute, Tianjin, 300410, China
}

Keywords: information teaching; higher vocational college; English course

\begin{abstract}
With information age coming, information teaching will be an important future teaching model in higher vocational college English course. There are many problems in current information teaching application of higher vocational college English course. Several suggestive strategies are proposed to promote the overall information teaching level of higher vocational college English course.
\end{abstract}

\section{Introduction}

As information resources and information technology develop rapidly in the $21^{\text {st }}$ century, vocational colleges combine their resource superiority to actively promote the course of information-based teaching. Information-based teaching brings opportunities and challenges to reform and update of existing teaching modes, teaching contents and teaching methods. How to rationally apply information-based teaching in vocational English course and give full play to its scientific and technical innovation and superiority? This is a topic we should boldly try.

Information-based teaching which is guided by modern teaching idea and supported by information technology applies modern teaching methods. In information-based teaching, a series of factors such as idea, organization, content, mode, technology, evaluation and environment should be informationized. Information-based teaching aims to apply information technology to better complete teaching. Its core is teaching and informatization is a means. As vocational English course reform deepens, information-based teaching becomes a significant teaching mode in future vocational English course.

\section{Status of application of information-based teaching in English course of vocational colleges and the problems}

1. At present, the degree of integration of information technology and vocational English course is not high and in knowledge-centered course integration stage. Under the assistance of information-based teaching, teachers often introduce or create vivid and concrete situations with certain emotional color according to teaching objectives so that students have the feeling of being personally on the scene. This can help students gain English communication competence required by teaching objectives. From the perspective of information-based teaching development, this is just basic application of information-based teaching.

2. As vocational colleges continuously develop and grow, their network information platform and hardware equipment for information-based teaching improve greatly, but the ability of English teachers in vocational collages to apply information technology in teaching is generally low. Most English teachers can only use multimedia classroom and language laboratory. The courseware used by English teacher in teaching mainly includes PPT they make or relevant videos downloaded from network. Information technology just plays the display function in vocational English teaching process.

3. In English class of vocational colleges, although students quite welcome information-based teaching mode, students' information accomplishment and the ability to apply information technology for self-study are low. Most students can untie network to collect information and accomplish assignments. They do not well apply information technology for self-study. Such situation seriously influences extended function of information-based teaching outside classroom. 


\section{Strategies to boost application effects of information-based teaching of English course in vocational colleges}

Information-based teaching of English course in vocational colleges not just alters teaching means, but also reforms teaching idea, teaching mode and teaching form. Information-based teaching in vocational English course is the only road to realize English education informationization and great-leap-forward development of English education. Meanwhile, in the course of English education informationization, English teachers' ability to apply information technology in teaching expands and core competitiveness of vocaiotnal colleges effectively improves.

1. Reform existing English teaching idea in vocational colleges. Aiming at vocational features of vocational colleges, the reform of English teaching idea should be based on personnel training objective of vocational colleges, refer to advanced experience of Chinese and foreign vocational colleges to widen horizon and advance with the times, gradually form the teaching idea matched with current situations of English teaching in vocational colleges and guide vocational colleges for information-based teaching.

To overall carry out information-based teaching of English in vocational colleges, English teachers in vocational colleges should alter educational idea, take active part in trainings for information-based teaching skills and boost individual information accomplishment and information-based teaching ability. The $21^{\text {st }}$ century is every-changing information era. English teachers in vocational colleges not only should own profound professional theoretical knowledge, but also need to master modern teaching methods. In the process of information-based teaching, English teachers in vocational colleges need to participate in teaching process, design and development of teaching resources. English teachers in vocational colleges are engaged in basic teaching work for a long term, so they own professional knowledge and teaching experience. Excellent courses and English course resource library developed by English teachers aim at vocational features of students in vocational colleges, own wide adaptation and can well satisfy students' learning needs.

2. Information-based teaching idea breaks through limitations of traditional class. English teachers change to students' guides from classroom dominators to guide students' study and life, organize, coordinate and help students to apply information-based teaching platform to gain information and knowledge. The training objective of vocational colleges pays more attention to "knowledge, information and ability" according to students' vocational features to help them become high-quality technical personnel in future vocational career. In information-based teaching process, teaching mode, teaching design and teaching contents change to different degrees. English teachers should focus on training students' ability to learn and work with information technology in teaching process. For example, during information-based teaching of English in vocational colleges, English teachers will require students preparing role play related to learning situations. Students need to utilize network to search information and make multimedia courseware for classroom presentation or situation setting. So, it is very necessary to boost students' information accomplishment.

During information-based teaching of English in vocational colleges, information accomplishment level of vocational college students directly influences information-based teaching effects. Vocational colleges can set up some elective courses such as information retrieval and software application for students according to practical situations. Through learning these information technology courses, vocational college students can own basic information accomplishment and gain learning initiative during information-based teaching of English in vocational colleges, independently apply various network information resources to obtain knowledge, information and ability, accomplish learning tasks and online test through campus information resource platform and complete online communication with teachers on campus network interaction platform. Under the guidance of English teachers, vocational college students utilize existing information technology teaching resources to master teaching contents and actively conduct expansion study after class to improve English teaching quality of vocational colleges. 
3. To reinforce construction of information-based teaching of English in vocational colleges is an effective approach to realize popularization of information-based teaching of English in vocational colleges. During construction of information-based teaching of English in vocational colleges, colleges should focus on overall situation and apply achievements of modern information technology on the basis of applications to establish network information platform combining vocational orientation and English teaching, integrate English education information resources, develop English teaching software, create favorable English information-based teaching atmosphere and provide resource guarantee for English practice teaching and industry-academy cooperation. Construction of information-based teaching of English in vocational colleges should own advancement and practicability and can satisfy the needs of English information-based teaching for figure, image, video and other large-traffic data exchange. Meanwhile, colleges should strive to create digital learning environment (including excellent English course, English resource library, English e-reading room and English interaction platform) so as to penetrate English information-based teaching into classroom teaching, student management and public service and construct vocational English education mode adapting requirements of information society.

In the process of construction of information-based teaching of English in vocational colleges, based on the principle of facilities and technologies serving English teaching, colleges should pay attention to creating real vocational environment and atmosphere according to practical situations. Construction of information-based teaching of English in vocational colleges means to carry out innovative expansion on the basis of existing information technology. English teachers should enhance information integration of information technology and English course, fully reflect advanced teaching idea, stress deep-level application of information technology, highlight changes in teaching structure, create relaxing, open, independent and initiative learning environment and mobilize students' enthusiasm to the largest extent.

\section{Conclusions}

English information-based teaching in vocational colleges not just boosts English teachers' ability to utilize information technology for English teaching, but also improves students' information accomplishment. Comprehensive implementation of English information-based teaching in vocational colleges needs front-line English teachers and researchers in educational technology to make joint efforts and unremitting pursuit.

\section{References}

[1] Huang Ronghuai, Information technology and education [M]. Beijing: Beijing Normal University Press, 2002, 10

[2] Zhou Bingyang, Study on current situation of higher vocational educational informationization and improvement strategy [J]. China Education Information, 2007,(2)

[3] Su Ying, On information-based teaching mode to cultivate students' information accomplishment [J]. Journal of Weifang University, 2010,8: 140-143

[4] Yu Shufang, Study on information-based teaching [M]. Beijing: Science Press, 2005: 1-6; 72- 74

[5] Zhu Zhiting, Modern educational technology [M]. Beijing: Higher Education Press, 2001: 179

[6] Yang Zhenyu, Collected works of Yang Zhenyu [M]. Shanghai: East China Normal University Press, 1998: 467 